\title{
Pengelolaan Kelembagaan Lelang Lebak Lebung dan Perilaku Nelayan di Kabupaten Muara Enim Provinsi Sumatera Selatan
}

\section{The Managing of Institutional Auction of Lebak Lebung and Fisherman Behavior in Muara Enim Regency Sumatra Selatan Province}

\author{
Enik Afri Yanti ${ }^{1}$, Arif Satria $^{2}$, Basita G. Sugihen ${ }^{2}$ \\ ${ }^{1}$ Program Studi Ilmu Penyuluhan Pembangunan, Sekolah Pascasarjana, Institut Pertanian Bogor, Bogor \\ ${ }^{2}$ Departemen Sains Komunikasi dan Pengembangan Masyarakat, \\ Fakultas Ekologi Manusia, Institut Pertanian Bogor, Bogor
}

\begin{abstract}
The study aims to (1) Analyzing attitude of the fishermen towards management system in Lebak Lebung (knowladge, behaviour, and manner), (2) to describing auction system of Lebak Lebung, (3) and to analyze the external and internal characteristic between the institutional and the fishermen towards open waters managed in Lebak Lebung. The study was conducted using survay methods thourgh decriptive analysis and corellation methode which the samples of this study are 100 fishermen in Muara Enim -Sub distict. The result showed that (1) Lebak Lebung is the open water district which consist of river area and land that forms marshes (lebak) and low land that watery (lebung). Lebak Lebung will be a fishes breeding in ebb season, and in the flow season Lebak Lebung used by villager to catch fishes. The ownership of fish resources in Lebak Lebung will be given to Pegemin auction as a winner of area Lebak Lebung thourgh aution system. The aims of Lebak Lebung-auction is to obtain the income areas, and conservation of Lebuk Lebung, and avoid the confilcts between fishermen. (2) the highly behaviour : Knowladge, behaviour, and manner of fihermen in Lubuk Lebung auctions management. (3) Internal characteristic, Lebak lebung institutional and external characteristics that relating to the behavior of fishermen is the level of education, the number of dependents experience of fishermen effort, income of the fishermen, rule, punishment, the performance of fishermen group, the government policy.
\end{abstract}

Keywords: auction, fishermen custom, institutional, Lebak Lebung,

Abstrak

Tujuan penelitian adalah untuk (1) Menganalisis perilaku nelayan (pengetahuan, sikap, tindakan) dalam mengelola perairan lebak lebung (2) Mendeskripsikan sistem lelang lebak lebung, (3) Menganalisis karakteristik internal, kelembagaan lebak lebung dan karakteristik eksternal nelayan yang mempengaruhi perilaku nelayan dalam mengelola perairan lebak lebung. Penelitian ini menggunakan metode survey dan dilaksanakan di Kabupaten Muara Enim. Jumlah sampel penelitian 100 orang nelayan. Metode analisis yang digunakan adalah deskriptif dan korelasi. Hasil penelitian menunjukkan bahwa: (1) Lebak lebung adalah perairan umum air tawar yang terdiri dari areal sungai dan tanah yang bentuk rawa-rawa (lebak) dan tanah rendah yang berair (lebung). Pada musim pasang lebak lebung menjadi tempat ikan berkembang biak dan pada musim surut dimanfaatkan masyarakat nelayan untuk menangkap ikan. Kepemilikan atau hak untuk menangkap ikan dan hasil perairan lebak lebung diberikan kepada pengemin lelang yang sudah memenangkan objek lebak lebung melalui kegiatan lelang. Lelang lebak lebung diselenggarakan dengan tujuan untuk memperoleh pendapatan daerah,pelestarian perairan lebak lebung, menghindari konflik antar nelayan.(2) Perilaku nelayan meliputi pengetahuan, sikap dan tindakan dalam pengelolaan perairan lebak lebung termasuk dalam kategori tinggi (3) Karakteristik internal, kelembagaan lebak lebung dan karakteristik eksternal yang berhubungan secara signifikan dengan perilaku nelayan adalah tingkat pendidikan, jumlah tanggungan pengalaman usaha nelayan, pendapatan nelayan, aturan, sanksi, kinerja kelompok nelayan, kebijakan pemerintah.

Kata kunci: kelembagaan, lelang, Lebak Lebung, perilaku nelayan

\section{Pendahuluan}

Provinsi Sumatera Selatan secara geografis sebagian besar wilayahnya berupa dataran rendah berupa sungai dan rawa atau yang lebih dikenal dengan istilah lebak lebung. Rawa lebak lebung merupakan rawa-rawa yang terdapat disekitar daerah aliran sungai
(DAS). Daerah ini tergenang saat musim penghujan dan kering saat musim kemarau. Perbedaan ketinggian air di rawa banjiran ini sangat ekstrim namun daerah ini sangat subur karena banyak mengandung unsur hara untuk pakan ikan terutama berasal dari proses dekomposisi vegetasi saat tergenang.

Sungai Musi dan rawa banjirannya merupakan

\footnotetext{
${ }^{1}$ Korespondensi penulis

E-mail: enik_afriyanti@yahoo.com
} 
tepian sungai yang sepanjang musim penghujan merupakan kawasan luapan air. Perairan ini berperan sangat penting dalam penyediaan komoditas dan jasa lingkungan, termasuk perikanan sehingga areal ini menjadi kantong ikan tangkapan. Memasuki musim kemarau, kawasan sungai dan rawa banjirannya mulai surut dan fungsinya berubah menjadi sawah lebak. Pemanfaatan rawa, lebak dan lebung untuk kegiatan perikanan masih belum optimal. Rawa banjiran atau disebut dengan istilah rawa lebak lebung, terdapat di sembilan kabupaten/kota di Sumatera Selatan yaitu Kota Palembang, Kabupaten Ogan Ilir, Ogan Komering 1lir,Banyuasin, Musi Banyuasin, Muara Enim, Musi Rawas, Ogan Komering Ulu, Ogan Komering Ulu Timur. Potensi perikanan perairan umum Kabupaten Muara Enim pada tahun 2013 terdiri dari: potensi sungai dengan luas areal 224,24 ha dengan produksi 1407,6 ton, potensi rawa lebak dengan luas areal $11,684,00$ ha dengan produksi 877,38 ton, potensi danau dengan luas areal 2646,80 ha dan produksi 707,31 ton. Secara keseluruhan luas areal dan produksi perikanan perairan umum di Kabupaten Muara Enim tahun 2013, dengan total luas areal $33,814,80$ ha, dengan total produksi $2,992,31$ ton.

Untuk menjaga kelestarian sumberdaya dan hasil tangkapan ikan maka diperlukan pengelolaan ekosistem perairan secara efektif dan terpadu. Salah satu cara pengelolaan yang telah lama diterapkan di Kabupaten Muara Enim adalah penetapan kawasan lelang lebak lebung pada perairan sungai, danau dan rawa. Kegiatan lelang lebak lebung pada pengelolaan sumberdaya perikanan yang dilakukan merupakan suatu cara yang mengandung peraturan yang berperan sangat penting dan bertujuan untuk menjaga keseimbangan antara kegiatan penangkapan ikan dengan ketersediaan sumberdaya ikan yang akan ditangkap, sehingga populasi ikan dapat dipertahankan kesinambungannya. Namun keseimbangan antara penangkapan ikan dengan ketersediaan sumberdaya ikan yang tidak mampu mempertahankan jumlah populasi ikan yang ada di perairan yang ada di wilayah tersebut, hal ini terlihat dari menurunnya produksi perikanan tangkap di wilayah tersebut. Selain itu dampak negatif dari lelang lebak lebung adalah menonjolnya unsur penguasaan dibanding pengelolaan sehingga perairan umum tidak lagi bersifat umum tapi menjadi milik satu atau sekelompok orang. Dari berbagai permasalahan diatas mengenai pengelolaan perairan lebak lebung maka diperlukan penelitian mengenai pengelolaan kelembagaan lebak lebung dan perilaku nelayan dalam mengelola perairan lebak lebung. Berdasarkan latar belakang tersebut, maka rumusan penelitian ini adalah: (1) Bagaimana perilaku nelayan (pengetahuan, sikap, tindakan) dalam mengelola perairan lebak lebung? (2) Bagaimana sistem lelang lebak lebung? (3) Bagaimana hubungan karakteristik internal, kelembagaan lebak lebung dan karakteristik eksternal nelayan terhadap perilaku nelayan dalam mengelola perairan lebak lebung?

Tujuan penelitian ini adalah (1) Menganalisis perilaku nelayan (pengetahuan,sikap, dan tindakan) dalam mengelola perairan lebak lebung (2) Mendeskripsikan sistem lelang lebak lebung (3) Menganalisis karakteristik internal, kelembagaan lebak lebung dan karakteristik eksternal nelayan yang mempengaruhi perilaku nelayan dalam mengelola perairan lebak lebung.

\section{Metode Penelitian}

Peubah independen penelitian ini adalah karakteristik internal, kelembagaan lebak lebung dan karakteristik eksternal yang meliputi umur, pendidikan formal, pengalaman kerja, jumlah tanggungan keluarga, pendapatan rumah tangga, tingkat kosmopolitan, sejarah, aturan, sanksi, kinerja kelompok dan kebijakan pemerintah, sedangkan peubah dependen penelitian ini adalah perilaku nelayan lebak lebung yang meliputi pengetahuan, sikap dan tindakan nelayan dalam mengelola perairan lebak lebung. Penelitian ini dilaksanakan pada November 2014 - Januari 2015 di Kabupaten Muara Enim, Sumatera Selatan dan menggunakan metode survei. Penentuan lokasi penelitian dilakukan secara purposive sampling. Jumlah populasi penelitian yaitu 140 orang nelayan/ pengemin lelang, berdasarkan perhitungan rumus Isaac dan Michael dalam Sugiyono (2011) untuk tingkat kesalahan 5\% diperoleh jumlah sampel penelitian yaitu 100 orang nelayan/pengemin lelang. Pengambilan sampel masing-masing desa ditentukan menggunakan teknik secara proportional simple random sampling. Analisis data dilakukan secara kuantitatif, dengan menggunakan analisis statistik deskriptif dan analisis korelasi rank Spearman. Uji korelasi rank Spearman dipilih dalam penelitian dengan pertimbangan bahwa peubah penelitan tingkat pengukurannya adalah ordinal.

Hasil analisis uji instrumentasi didapat seluruh butir pernyataan dalam instrumen penelitian dinyatakan valid. Hal ini terlihat dari nilai $r$ hitung 
yang berkisar dari 0,357 sampai dengan 0,883 , nilai ini lebih besar daripada nilai $r$ tabel yaitu 0,349 pada taraf nyata lima persen. Hasil uji coba instrumen juga menunjukkan bahwa nilai koefisien reliabilitas alpha cronbach pada seluruh variabel (kelembagaan lebak lebung, karakteristik eksternal, dan perilaku nelayan) termasuk kategori reliabel dengan kisaran nilai koefisien reliabilitas alpha cronbach yaitu 0,426 sampai. dengan 0,873 .

\section{Hasil dan Pembahasan}

\section{Karakteristik Internal Nelayan}

Karakteristik internal nelayan dalam penelitian ini meliputi umur nelayan, tingkat pendidikan, jumlah tanggungan keluarga nelayan, pendapatan nelayan, pengalaman kerja dan tingkat kekosmopolitan.
Hasil penelitian menunjukkan bahwa umur nelayan didominasi oleh golongan umur 41-50 tahun, dengan rataan umur 47,8 tahun. Berdasarkan kelompok umur tersebut, maka dapat diartikan bahwa secara fisik nelayan memiliki potensi atau kemampuan untuk bekerja melakukan penangkapan ikan sesuai dengan keterampilan dan pengalaman yang mereka miliki dalam mengelola sumber daya perairan lebak lebung yang mereka miliki. Hal ini sejalan dengan penelitian Pakpahan (2006) bila dipandang dari usia produktif, maka usia nelayan dapat dikatakan bahwa usia produktif, berarti nelayan memiliki kemampuan fisik yang baik. Kondisi fisik yang baik akan membuat nelayan mampu melakukan kegiatan sacara optimal dan mampu mengembangkan diri dengan mengutamakan keberhasilan demi tercipta kesejahteraan bagi keluarganya.

Pendidikan merupakan satu hal yang paling

Tabel 1 Karakteristik internal nelayan Lebak Lebung

\begin{tabular}{|c|c|c|c|}
\hline Karakteristik Internal & Kategori & Jumlah (Orang) & Persentase $(\%)$ \\
\hline Umur nelayan (tahun) & Muda $(20-40)$ & 14 & 14,0 \\
\hline \multirow[t]{2}{*}{ Rataan $=47,8$} & Dewasa $(41-50)$ & 44 & 44,0 \\
\hline & Tua $(>50)$ & 42 & 42,0 \\
\hline Tingkat pendidikan nelayan & Rendah (tidak tamat SD - tamat SD) & 34 & 34,0 \\
\hline \multirow[t]{2}{*}{ Rataan $=84,2$} & Sedang (tidak SLTP - tamat SLTP) & 51 & 51,0 \\
\hline & Tinggi (tidak tamat SLTA-PT) & 15 & 15,0 \\
\hline \multirow{2}{*}{$\begin{array}{l}\text { Jumlah tanggungan keluarga } \\
\text { nelayan }\end{array}$} & $\operatorname{Kecil}(2-3)$ & 28 & 28,0 \\
\hline & Sedang $(4-5)$ & 47 & 47,0 \\
\hline Rataan $=4,2$ & Besar $(6-7)$ & 25 & 25,0 \\
\hline \multirow{2}{*}{$\begin{array}{l}\text { Pendapatan rumah tangga } \\
\text { nelayan }\end{array}$} & Rendah (Rp 2.400.000) & 18 & 18,0 \\
\hline & Sedang (Rp 2.400.000 - Rp 3.100.000) & 39 & 39,0 \\
\hline Rataan $=\operatorname{Rp} 2.865 .000$ & Tinggi (> Rp 3.200.000) & 43 & 43,0 \\
\hline Pengalaman kerja nelayan & Baru (2 - 12 tahun) & 7 & 7,0 \\
\hline \multirow[t]{2}{*}{ Rataan $=14,9$} & Sedang (13 - 16 tahun $)$ & 22 & 22,0 \\
\hline & Lama ( $>17$ tahun). & 71 & 71,0 \\
\hline Tingkat kekosmopolitan & Rendah $(<4$ kali) & 34 & 34,0 \\
\hline \multirow[t]{2}{*}{ Rataan $=2,8$} & Sedang (5 kali) & 45 & 45,0 \\
\hline & Tinggi ( $>6$ kali) & 21 & 21,0 \\
\hline
\end{tabular}


penting dalam menunjang kemajuan pembangunan suatu daerah. Tingkat pendidikan akan mempengaruhi pola pikir masyarakat, baik yang diperoleh melalui jenjang pendidikan formal maupun informal. Berdasarkan hasil penelitian dapat dilihat bahwa tingkat pendidikan yang paling mendominasi adalah golongan tidak tamat SLTPtamat SLTP sebanyak 51,0\% dengan kategori sedang, dengan rataan 84,2. Berbeda dengan penelitian Pakpahan et al., (2006) bahwa tingkat pendidikan nelayan yang pada umumnya rendah. Tingkat pendidikan responden diwilayah ini menunjukkan bahwa kualitas sumberdaya manusia khususnya nelayan di Kecamatan Sungai Rotan cukup baik, mengingat minimnya sarana dan prasarana pendidikan yang tersedia dikecamatan sungai rotan, namun hal tersebut tidak menjadi penghalang bagi nelayan untuk menempuh pendidikan hingga keluar wilayah Kecamatan Sungai Rotan. selanjutnya perlu adanya peningkatan kualitas sumberdaya manusia yang lebih baik lagi untuk mengembangkan potensi daerah ini. Menurut Hartati et al., (2005) salah satu cara yang dapat ditempuh untuk meningkatkan sumberdaya manusia melalui upaya peningkatan minat anak dan orangtua untuk melanjutkan pendidikan ke jenjang yang lebih.

Besar kecilnya jumlah tanggungan keluarga akan mempengaruhi pola kehidupan yang menyangkut pendapatan dan pengeluaran dalam rangka memenuhi kebutuhan hidup rumah tangganya. Berdasarkan penelitian dapat dilihatbahwa jumlahtanggungankeluargadidominasi oleh 47 orang nelayan atau sebanyak 47,0\% dengan rataan 4,2 orang tanggungan. Banyaknya anggota keluarga dalam keluarga nelayan dapat dijadikan modal tenaga kerja bagi keluarganya dalam membantu perekonomian keluarga dengan kontribusi pendapatan yang dihasilkan, namun kenyataan dilapangan menunjukkan bahwa responden masih memiliki tanggungan dalam usia belum produktif (usia sekolah). Semakin banyak anggota keluarga maka semakin banyak pula kebutuhan yang harus dipenuhi oleh keluarga. Hal tersebut menuntut nelayan untuk bekerja keras dengan alasan untuk memenuhi kebutuhan ekonomi keluarga mereka.

Tinggi rendahnya pendapatan responden nelayan akan mempengaruhi kemampuan daya beli nelayan tersebut untuk memenuhi kebutuhan konsumsi rumah tangganya maupun sarana produksi usaha mereka. Hasil penelitian menunjukkan sebanyak 43,0\% responden memiliki pendapatan dalam kategori tinggi dengan rataan pendapatan perbulan senilai Rp 2.865.000. Menurut Hartati et al, (2005) tingginya nilai pendapatan yang diperoleh nelayan memiliki kecenderungan untuk dijadikan sebagai usaha pokok bagi nelayan.

Pengalaman kerja merupakan bekal bagi para nelayan untuk melakukan kegiatan usaha penangkapan ikan, untuk meningkatkan produktivitas mereka harus didukung dengan keahlian dan diikuti oleh pengalaman yang dibidang penangkapan ikan. Berdasarkan hasil penelitian dapat dilihat bahwa pengalaman kerja responden didominasi oleh pengalaman lama atau dapat disebut responden sangat berpengalaman sebanyak 71,0\% responden termasuk dalam kategori tinggi dengan rataan 14,9 tahun. Sejalan dengan penelitian Hartati et al., (2005) bahwa responden ratarata telah menjalani usaha selama 14,3 tahun. Lama berusaha (pengalaman) responden dalam menjalankan kegiatan usahanya telah memberikan gambaran bahwa antar responden memiliki jangka waktu berusaha yang hampir sama. Pengalaman yang dimiliki responden dalam usahanya merupakan salah satu modal responden dalam meningkatkan produktivitas usaha penangkapan ikan diperairan lebak lebung.

Pada penelitian ini tingkat kekosmopolitan dilihat dari frekuensi responden mengunjungi daearah lain, frequensi responden mengunjungi sumber informasi dan mencari informasi tentang perikanan. Hasil penelitian menunjukkan bahwa tingkat kekosmopolitan nelayan didominasi oleh $45,0 \%$ responden memiliki tingkat kekosmopolitan dalam kategori sedang dengan rataan 2,8 kali. Rendahnya minat responden untuk mengunjungi daerah lain dalam upaya mencari informasi tentang perikanan menjadi salah satu penyebab kurang berkembangnya inovasi dalam pengelolaan perikanan diwilayah penelitian khususnya pengelolaan perikanan lebak lebung. Nelayan lebih mengutamakan kegiatan penangkapan pada lokasi objek lebak lebung yang mereka miliki guna mendapatkan hasil yang maksimal, tanpa memperdulikan keberlanjutan ekosistem perairan yang ada.

\section{Penangkapan Ikan Perairan Lebak Lebung}

Pemanfaatan sumberdaya perikanan perairan umum secara luas dan efisien merupakan tuntutan dalam pembangunan nasional. Perairan umum terdiri dari danau, waduk, rawa, lebak, sungai serta genangan lainnya, merupakan salah satu sumberdaya perairan yang potensial untuk lebih dikembangkan dalam memenuhi kebutuhan pangan bagi manusia, khususnya kebutuhan protein hewani dari ikan. Pemanfaatan perairan umum tersebut umumnya 
Tabel 2 Jenis alat tangkap dan ikan tangkapan yang diizinkan pada perairan umum di Kabupaten Muara Enim

\begin{tabular}{ll}
\hline Alat Tangkap & \multicolumn{1}{c}{ Hasil Tangkapan } \\
\hline Jaring insang (Bubu) & Betok (Anabas testudineus), siapil (Helostoma \\
& temmincki) 1 , sepat siam (trychogaster pectoralis), \\
& sepat mato abang (trychogaster trichopterus, selinca \\
& (Polycantihushaselti), Kepras (puntioplites waandersi), \\
& Udang (macrobrachium sp), belut (monopterus sp) \\
Pancing & Betok (anabas testudineus), Gabus (channa striata), \\
& Lais (kryptopterus schilbeides), Baung (mystus \\
& nemurus), Lampam (barbodes schwanenfeldii), \\
& Juaro (pangasius polyuranodon), Patin (pangasius \\
& pangasius), Toman (Channa micropeltes), Bujuk \\
Rawai & (Channa lucius) \\
& Juaro (pangasius polyuranodon), Patin (pangasius \\
pangasius), Lais (kryptopterus schilbeides), Baung & (mystus nemurus), Lampam (barbodes schwanenfeldii) \\
Tangkul & Lambak (thycnichthys polylepis), Seluang (rasbora \\
& spp), Riu-riu (pseudeutropius brachypopterus) \\
\hline
\end{tabular}

dilakukan melalui kegiatan penangkapan ikan. Produksi perikanan perairan umum sebagian besar didominasi oleh produksi penangkapan. Perairan umum lebak lebung mempunyai potensi yang kaya akan ikan, adapun jenis ikan yang sering didapatkan oleh nelayan/pengemin lelang antara lain: ikan toman (Channamicropeltes), ikanbujuk (Channalucius), ikan selais (Cryptoterus biccirchis), ikan baung (Mystus nemurus), ikan selinca (Polycantihus haselt), ikan siapil (Helostoma temminck), ikan motan (Tinictis polylephis), ikan sepat siam (Trichogaster pectoralis). Ikan betok (Anabas testudineus). Selanjutnya alat tangkap yang diizinkan oleh lembaga lebak lebung yang digunakan nelayan dalam melakukan usaha penangkapan ikan adalah jaring insang, bubu, rawai, tangkul, dan pancing, namun selain terdapat jenis alat tangkap yang dilarang namun hingga saat ini masih digunakan oleh nelayan/pengemin, yaitu langsatan (dioperasikan secara menetap). Langsatan adalah alat penangkapan ikan yang berbentuk jaring berkantong dan dioperasikan dengan metode menghadang ruaya (migrasi) ikan di perairan sungai, selain itu alat penangkapan ikan yang dilarang adalah dengan menggunakan bahan kimia, bahan peledak, dan aliran listrik/setrum (Tabel 2).

Aktivitas penangkapan ikan yang dilakukan nelayan pengemin dengan menggunakan jenis alat tangkap yang terdapat pada tabel 2. Kegiatan penangkapan ikan yang dilakukaan nelayan pengemin lelang di perairan objek lebak lebung pada saat musim kemarau merupakan puncaknya karena pada musim kemarau ikan terkonsentrasi pada tempat-tempat tertentu yang masih digenangi air. Aktivitas penangkapan ikan diobjek lebak lebung pada musim kemarau berdampak sangat negatif terhadap kondisi periaran dan ekosistemnya karena aktivitas penangkapan ikan yang dilakukan oleh nelayan pengemin cenderung menghabiskan sumberdaya ikan hal ini disebabkan oleh nelayan pengemin dengan mudah menangkap ikan pada perairan objek lebak lebung, selain itu kebiasaan nelayan pengemin menangkap semua sumberdaya ikan yang ada. Nelayan akan berusaha menangkap ikan dengan segala daya upaya, menggunakan semua teknik penangkapan ikan yang mereka kuasai untuk memperoleh hasil sebesar-besarnya (Nasution, 2012). Pada tabel 3 menjelaskan jumlah produksi hasil tangkapan nelayan perbulan.

\section{Kelembagaan Penyuluhan Perikanan}

Kelembagaan penyuluhan perikanan untuk tingkat kabupaten adalah Badan Pelaksana Penyuluhan Pertanian Perikanan dan Kehutanan (BP4K), yang memiliki fungsi dantugas pokok dengan cara pelaksanaan sesuai kebutuhan serta program pada masin-masing sektor tingkat kabupaten. Pada tingkat kabupaten, Kabupaten Muara Enim memiliki penyuluh pertanian lapangan sebanyak 235 orang penyuluh PNS dan THL, sedangkan pada tingkat kecamatan, Kecamatan Sungai Rotan memiliki penyuluh pertanian lapangan sebanyak 
Tabel 3 Hasil tangkapan nelayan dalam satu bulan di Kabupaten Muara Enim

\begin{tabular}{lcc}
\hline \multicolumn{1}{c}{ Hasil Tangkapan (Kg) } & Jumlah (jiwa) & Persentase (\%) \\
\hline $50-100$ & 14 & 14,0 \\
$100-200$ & 73 & 73,0 \\
$>200$ & 13 & 13,0 \\
\hline Jumlah & 100 & 100,0 \\
\hline
\end{tabular}

Keterangan $\mathrm{n}=100$

17 orang yang terdiri dari PNS dan THL. Tugas yang harus dilakukan oleh penyuluh sifatnya tidak hanya menangani satu sektor saja, tetapi penyuluh menangani seluruh sektor yang ada pada wilayah kerjanya. hingga saat dilaksanakannya penelitian ini, belum ada petugas penyuluh yang melapor kepada kepala desa terkait program penyuluhan baik dibidang perikanan maupun pertanian. Kelemahan kinerja penyuluh dipengaruhi oleh, sebagian besar penyuluh tidak berdomisili diwilayah binaan, belum terlaksananya koordinasi yang baik antara penyuluh dengan pihak pemerintah desa, latar belakang pendidikan (Marliati et al., 2008).

Penyuluh swadaya menurut Undang Undang Nomor 16 Tahun 2006 tentang Sistem Penyuluhan Pertanian, Perikanan, dan Kehutanan adalah pelaku utama yang berhasil dalam usahanya dan warga masyarakat lainnya yang dengan kesadarannya sendiri mau dan mampu menjadi penyuluh. Selama ini umumnya penyuluh perikanan swadaya juga merupakan pengurus intikelompokatau pernahmenjadi pengurus inti kelompok pelaku utama perikanan. Pada prakteknya secara umum, penyuluh perikanan swadaya bekerja sama dengan penyuluh perikanan PNS mensinergikan berbagai kegiatan penyuluhan untuk pelaku utama perikanan. Berdasarkan pengamatan diwilayah ini tidak terdapat penyuluh swadaya baik dibidang perikanan maupun pertanian umumnya. Hal ini disebabkan oleh kurangnya perhatian pemerintah terhadap usaha perikanan atau pertanian, selain itu terbatasnya kemampuan atau keterampilan yang dimiliki oleh nelayan juga menjadi salah satu penyebab kurang berkembangnya usaha perikanan diwilayah ini.

Terkait dengan pelaksanaan penyuluhan ditingkat desa, selama ini belum pernah dilakukan kegiatan penyuluhan perikanan perairan umum atau upaya rehabilitasi terhadap wilayah kritis terutama perairan umum lebak lebung. Kurangnya perhatian pemerintah atau lembaga terkait dalam upaya pengawasan dan pengelolaan perairan umum lebak lebung menyebabkan semakin berkurannya sumberdaya ikan yang terdapat diperairan umum wilayah Kecamatan Sungai Rotan. Permasalahan yang terjadi dapat disimpulkan bahwa lembaga penyuluhan perikanan belum berfungsi sepenuhnya sebagai wadah untuk mengatasi permasalahan dan upaya pemecahannya.

\section{Kelembagaan Lebak Lebung}

Lebak lebung merupakan perairan umum air tawar yang terdiri dari sungai, danau dan tanah yang bentuk rawa-rawa (lebak) dan bagian tanah rendah yang tergenang air (lebung). Pada musim pasang lebak lebung menjadi tempat ikan berkembang biak dan pada musim surut dimanfaatkan masyarakat untuk menangkap ikan. Sejalan dengan pendapat Nasution (2008) perairan umum lebak lebung adalah perairan umum air tawar yang memiliki ciri spesifik yang berbeda dengan perairan umum lainnya. Secara garis besar, habitat utama pada perairan umum lebak lebung dapat dikelompokkan menjadi 4 tipe yaitu bagian sungai utama, lebak kumpai, talang dan rawang (Arifin, 1978).

Pelaksanaan sistem lelang lebak lebung menurut sejarah dimulai pada zaman kesultanan palembang dan diteruskan pada zaman belanda dengan adanya pemberian kuasa penuh kepada pemerintah marga yang diketuai oleh seorang pasirah sebagai penguasa. Namun saat ini sistem lelang lebak lebung dibawah pengaturan pemerintah daerah, kewenangan dan juga pengawasan dibawah pemerintah Kabupaten Muara Enim. Lelang lebak lebung dilaksanakan Pemerintah Daerah Kabupaten Muara Enim khususnya pemerintah desa setiap tahunnya dimana lelang lebak lebung ini merupakan salah satu sumber pendapatan asli daerah Kabupaten Muara Enim. Kelembagaan formil yang melakukan pelaksanaan lelang lebak lebung adalah pemerintah daerah, dengan penanggungjawab Bupati Kabupaten Muara Enim dan pelaksana pemerintah desa, hal ini sesuai dengan diterbitkannya peraturan daerah No. 5/DPRD-GR/1987 lelang lebak lebung dalam kabupaten tingkat II Kabupaten Muara Enim, kemudian peraturan tersebut disambung sesuai instruksi bupati Kabupaten 


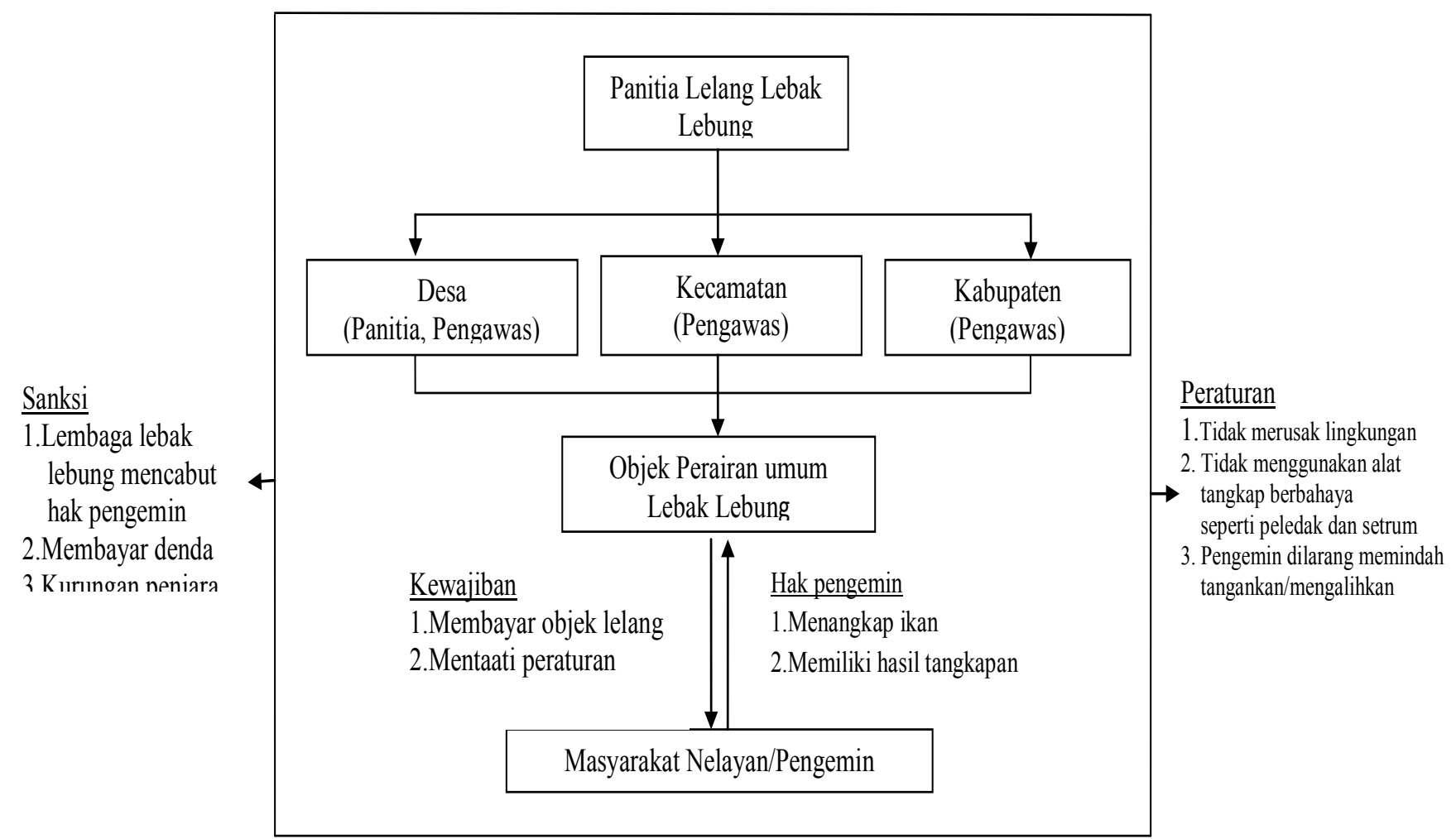

Gambar 1 Alur sistem lelang lebak lebung

Muara Enim No. 03/inst/IV/1998 tentang penghentian pemungutan pajak daerah dan retribusi daerah Kabupaten Muara Enim, karena lelang lebak lebung perlu diatur oleh pemerintah daerah, dengan telah diserahkan objek lelang lebak lebung kepada desa melalui surat Bupati Kabupaten Muara Enim tanggal 19 september 1998 No.140/2147/ II/1998 tentang penyerahan objek lelang lebak lebung dari Kabupaten Muara Enim kepada desa. Berdasarkan surat keputusan tersebut untuk pelaksanaan lelang lebak lebung diperlukan peraturan di tingkat desa sesuai dengan surat keputusan desa. Selanjutnya untuk pelaksanaan lelang lebak lebung pemerintah desa membentuk panitia pelaksana lelang. Terkait dengan pelaksanaan kegiatan lelang lebak lebung panitia lelang harus merencanakan dan mempersiapkan kegiatan lelang dimulai dari penetapan waktu pelaksanaan lelang, sosialisasi kepada masyarakat nelayan, pendaftaran peserta lelang hingga pelaksanaan lelang.

Peserta lelang adalah orang atau badan hukum yang telahterdaftarpadapanitiadanmemenuhipersyaratan sesuai dengan ketentuan bagi peserta yaitu berdomisili dalam wilayah kecamatan atau desa tempat objek lebak lebung. Penetapan jumlah dan objek lelang lebak lebung setiap tahunnya ditetapkan oleh kepala desa yang berada dilokasi penelitian sesuai dengan hasil musyawarah desa dengan masyarakat daerah setempat. Jadwal pelaksanaan lelang lebak lebung di lapangan telah sesuai dengan surat keputusan kepala desa, panitia lelang lebak lebung dan pengawas lelang kecamatan yang telah mengatur dan menetapkan waktu pelaksanaan lelang. Perairan objek lebak lebung yang tidak terjual pada saat lelang maka bagi masyarakat nelayan yang berminat dapat mengajukan permohonan tertulis pada panitia lelang lebak lebung dengan mencantumkan besarnya kemampuan pemohon terhadap objek lebak lebung yang diinginkan, namun jika perairan objek lebak lebung benar-benar tidak terjual dan tidak ada peminatnya maka secara otomatis perairan objek lebak lebung tersebut menjadi hak pemerintah desa/ lembaga lebak lebung, pemerintah desa memiliki hak sepenuhnya untuk mengelola perairan objek lebak lebung kemudian dari hasil usaha yang dilakukan terhadap objek tersebut sepenuhnya dimasukkan kedalam kas desa sebagai pendapatan asli desa (PAD). Kepemilikan atau hak untuk menangkap ikan dan hasil perairan lebak lebung diberikan kepada pengemin lelang yang sudah memenangkan objek lebak lebung melalui kegiatan lelang. Lelang lebak lebung diselenggarakan dengan tujuan untuk memperoleh pendapatan daerah, pelestarian perairan lebak lebung, menghindari konflik antar nelayan.

Pengemin memiliki hak secara umum yaitu: lebak lebung yang telah dilelang hasilnya hanya boleh diambil yang berhak. Selain itu setiap orang dilarang menangkap, memancing, mengambil ikan, udang dan sejenisnya tanpa izin dari pemenang 
Tabel 4 Susunan panitia pelaksana lelang Lebak Lebung

\begin{tabular}{|c|c|c|c|}
\hline No & & Jabatan & Keterangan \\
\hline \multirow[t]{4}{*}{1} & Ketua panitia & Kepala desa yang bersangkutan & \multirow{3}{*}{ Panitia dan pengawas } \\
\hline & Sekretaris & Sekretaris desa & \\
\hline & Anggota & Beberapa orang pembantu sesuai & \\
\hline & & kebutuhan yang ditunjuk oleh kepal desa & \multirow{6}{*}{ Pengawas } \\
\hline \multirow[t]{5}{*}{2} & Koordinator & Camat Sungai Rotan & \\
\hline & \multirow{4}{*}{ Anggota } & Sekretaris Kecamatan Sungai Rotan & \\
\hline & & Kapolsek Sungai Rotan & \\
\hline & & dibantu oleh petugasnya sesuai & \\
\hline & & kebutuhan & \\
\hline \multirow[t]{6}{*}{3} & K Koordinator & Kepala Badan Pemberdayaan Masyarakat & \multirow{6}{*}{ Pengawas } \\
\hline & & Kab.Muara Enim & \\
\hline & Sekretaris & Sekretaris BPMD Kab. Muara Enim & \\
\hline & Anggota & Kepala Bidang Pemberdayaan Masyarakat & \\
\hline & & dibantu oleh Kepala Bidang Pemerintahan & \\
\hline & & Desa & \\
\hline
\end{tabular}

Sumber: Kantor Kecamatan Sungai Rotan

lelang/pengemin. Satu hal yang paling penting dalam kegiatan lelang lebak lebung adalah pembagian hasil lelang lebak lebung ini adalah nilai yang diperuntukkan meningkatkan pendapatan asli daerah (PAD) Kecamatan Sungai Rotan yaitu 65\% dari hasil lelang di peruntukkan kas desa kemudian dari dana tersebut pemerintah desa mengalokasikan untuk kegiatan pembangunan (sarana/prasarana desa) 50\%, kegiatan rutin $30 \%$ dan kegiatan pengawasan objek lelang lebak lebung 20\%. Selanjutnya pembagian hasil lelang 5\% digunakan untuk biaya pelaksanaan lelang, 10\% diperuntukkan kepada panitia pelaksana lelang, 10\% diperuntukkan kepada panitia pengawas dari tingkat kecamatan, dan $10 \%$ diperuntukkan kepada pengawas dari tingkat Kabupaten Muara Enim.

Sistem lelang lebak lebung hingga saat ini pengelolaannya masih terbatas pada kegiatan penangkapan saja oleh pengemin atau pemenang lelang yang pada umumnya adalah orang yang memiliki modal kuat didaerah perairan lelang tersebut. Penangkapan ikan yang dilakukan oleh pengemin atau pemenang lelang cenderung merusak sumberdaya yang ada karena pengemin merasa tidak mempunyai kepentingan lagi terhadap perairan tersebut setelah kontrak lelangnya selesai, hal inilah yang menjadi salah satu alasan pengemin untuk menangkap ikan sebanyak mungkin demimengutamakan pendapatannya sehingga terjadinya over fishing. Menurut Nulhakim dalam Rifai (2002) gejala eksploitasi besar besaran disepanjang sunga musi dapat terlihat dari terjadinya kelangkaan jumlah ikan yang ditangkap oleh nelayan lokal akhir-akhir ini menunjukkan keprihatianan dari hasil tangkapan mereka.

\section{Sejarah Lelang Lebak Lebung}

Pengelolaan perikanan perairan umum lebak lebung di Sumatera Selatan (Sumsel), pertama kali ditetapkan pemerintahan marga yaitu pada tahun 1830 . Masa pemerintahan marga adalah sistem pemerintahan yang dilaksanakan di Sumsel sebelum dibentuknya desa-desa. Setelah ada pengarahan dari pemerintah pusat kepada daerah Sumatera Selatan, maka dikeluarkan Perda Tk. IProp. Sumsel No:8/Perdass/1973/1974 tgl. 14 Juli 1974 Tentang Lelang Lebak Lebung yang mengatur keseragaman peraturan tata cara lelang perairan di Prop. Sumsel. Kemudian disempurnakan melalui Perda Tk.I Prop. Sumsel No: 6 Tahun 1978 tentang perubahan pengaturan lelang lebak lebung. Akhirnya berdasarkan SK Gubernur KDH Tk. I Prop. Sumsel No: 705/Kpts/ II/1982 tgl 5 November 1982 pengaturan lelang ini dilimpahkan wewenang pelaksanaannnya kepada Pemerintah Dati II. 
Tabel 5 Kelembagaan lelang Lebak Lebung

\begin{tabular}{llcc}
\hline Kelembagaan Lelang Lebak Lebung & Kategori & Jumlah (Orang) & Persentase (\%) \\
\hline Sejarah & Kurang & 37 & 37,0 \\
& Cukup & 20 & 20,0 \\
\multirow{4}{*}{ Peraturan } & Baik & 43 & 43,0 \\
& Kurang & 39 & 39,0 \\
& Cukup & 20 & 20,0 \\
\multirow{3}{*}{ Sanksi } & Baik & 41 & 41,0 \\
& Kurang & 19 & 19,0 \\
& Cukup & 38 & 38,0 \\
& Baik & 43 & 43,0 \\
\hline
\end{tabular}

Keterangan: $\mathrm{n}=100$

Kelembagaan lelang lebak lebung dalam penelitian meliputi sejarah lebak lebung, aturan lelang lebak lebung dan sanksi lelang lebak lebung. Kegiatan lelang lebak lebung bertujuan untuk menghindari konflik antar nelayan atau masyarakat dalam melakukan kegiatan usaha penangkapan ikan diperairan, selain itu penghasilan dari kegiatan lelang lebak lebung juga diutamakan untuk kas desa sebagai pendapatan asli desa (PAD). Menurut Nasution (2012) kelembagaan tersebut lebih diarahkan untuk meningkatkan Pendapatan Asli Daerah (PAD) daripada untuk kepentingan masyarakat nelayan. Selanjutnya Daris et al., (2012 ) mengatakan bahwa kelembagaan lokal yang berperan dalam pengelolaan dan penyelesaian konflik nelayan yaitu; kelembagaan lokal tradisional (asli) dan kelembagaan lokal bentukan. Peran kelembagaan lokal asli dalam pengelolaan sumberdaya perikanan tangkap adalah pemanfaat dan pelestari sumberdaya, sedangkan kelembaagan lokal bentukan adalah pelestari dan pengawas sumberdaya. Peran kelembagaan lokal asli dalam pencegahan dan penyelesaian konflik adalah fasilitator, mediator, dan sebagai alat kontrol sosial masyarakat dalam berperilaku dan bertindak, sedangkan peran kelembagaan lokal bentukan adalah fasilitator, mediator, dan melaksanakan pengawasan dan sosialisasi peraturan pemerintah.

Hasil penelitian menunjukkan pemahaman responden terhadap sejarah lelang lebak lebung dalam kategori baik yakni sebanyak 43,0\%. Hal ini dapat diartikan bahwa pemahaman responden terhadap sejarah lelang lebak lebung ini masih cukup baik, namun dapat dilihat juga bahwa tidak sedikit dari responden kurang mengetahui dan memahami sejarah lelang lebak lebung itu sendiri karena yang terpenting bagi mereka dapat melakukan kegiatan penangkapan ikan di perairan tersebut. Wilayah Kecamatan Sungai Rotan pengelolaan perairan umum lebak lebung dengan cara dilelang ini sudah dilakukan secara turun temurun oleh nenek moyang mereka, hingga saat ini lelang lebak lebung masih tetap dipertahankan oleh masyarakat dan pemerintah daerah khususnya pemerintah desa. Lelang lebak lebung memberikan dampak positif bagi nelayan khususnya nelayan yang menjadi pengemin lelang, karena dapat mengembangkan usaha penangkapan ikan serta pengemin mampu menyerap tenaga kerja dalam melakukan usahanya, selain itu dengan adanya lelang lebak lebung mampu meningkatkan pendapatan asli desa bagi daerah, hingga saat ini masyarakat nelayan masih mendukung sepenuhnya pengelolaan perairan umum lebak lebung dengan cara di lelang, karena menurut responden dengan adanya lelang lebak lebung ini banyak sekali memberikan dampak positif bagi masyarakat setempat di antaranya terhindar dari konflik antar nelayan, sebagai sumber mata pencaharian utama, serta sebagai sumber pendapatan asli daerah.

\section{Peraturan dalam Lelang Lebak Lebung}

Aturan-aturan/tradisi lelang lebak lebung pada awalnya diwarisi secara turun temurun yang disebut juga sebagai hukum adat dan berlaku bagi masyarakat. Namun pada kenyataannya aturan dan hukum adat tersebut cukup efektif dalam pengelolaan sumberdaya perikanan perairan umum, dan menjaga pelestarian ekosistem perairan dari 
Tabel 6 Karakteristik eksternal nelayan Lebak Lebung

\begin{tabular}{llcc}
\hline \multicolumn{1}{c}{ Karakteristik Eksternal } & \multicolumn{1}{c}{ Kategori } & Jumlah (Orang) & Persentase(\%) \\
\hline Kinerja kelompok nelayan & Kurang & 43 & 43,0 \\
& Cukup & 23 & 23,0 \\
\multirow{3}{*}{ Kebijakan pemerintah } & Baik & 34 & 34,0 \\
& Kurang & 39 & 39,0 \\
& Cukup & 21 & 21,0 \\
& Baik & 40 & 40,0 \\
\hline
\end{tabular}

Keterangan: $\mathrm{n}=100$

berbagai aktivitas yang bersifat merusak. Menurut Stanis (2005) adanya pengaturan lokal dalam pengelolaan sumberdaya perikanan dan kelautan dipengaruhi oleh masalah pokok yaitu konflik antar nelayan. Munculnya konflik dalam kegiatan pemanfaatan atas sumberdaya perikanan dipengaruhi oleh rusaknya lingkungan (ekologi), pertambahan penduduk (demografi), lapangan pekerjaan yang semakin sedikit (mata pencaharian), lingkungan politik lokal, perubahan teknologi dan perubahan pasar. Dari berbagai permasalahan diatas maka pemerintah harus menegakkan peraturan dengan tegas dalam pengelolaan lelang lebak lebung. Aturan-aturan yang harus dipatuhi oleh nelayan saat melakukan penangkapan ikan diperairan umum untuk menjaga lingkungan perairan dan ekosistemnya. Menurut Evans (2014) bahwa aturan formal memiliki kekuatan yang cukup untuk menggusur atau mengubah perilaku manusia.

Pengelolaan perairan umum lebak lebung melalui kegiatan lelang hingga saat ini semakin berkembang sehingga diperlukan peraturan yang tegas dalam pelaksanaanya, sehingga Pemerintah Daerah Kabupaten Muara Enim, mengeluarkan peraturan untuk para pengemin atau pemenang lelang diantaranya pengemin memiliki hak secara umum yaitu: lebak lebung yang telah dilelang hasilnya hanya boleh diambil yang berhak. Selain itu setiap orang dilarang menangkap, memancing, mengambil ikan, udang dan sejenisnya tanpa izin dari pemenang lelang/pengemin. Selanjutnya pemenang lelang/pengemin memiliki kewajiban dan larangan yang harus dipatuhi yaitu (1). Mencegah perbuatan yang mengakibatkan pencemaran dan kerusakan sumberdaya ikan serta lingkungan (2). Pengemin yang objek lelangnya digunakan untuk lalu lintas umum harus menyediakan jalur jalan atau pintu air keluar untuk kelancaran lalu lintas umum (3). Tidak dibenarkan mengganggu tanaman padi para petani yang bersawah disekitar areal penangkapan ikan (4). Tidak dibenarkan menggunakan alat peledak, racun, listrik, serta bahan kimia yang berbahaya yang dapat merusak ekosistem perairan lebak lebung dalam usaha mengambil

Tabel 7 Perilaku nelayan di Kabupaten Muara Enim

\begin{tabular}{llcc}
\hline \multicolumn{1}{c}{ Perilaku Nelayan } & \multicolumn{1}{c}{ Kategori } & Jumlah (Orang) & Persentase (\%) \\
\hline Pengetahuan & Kurang & 25 & 25,0 \\
& Cukup & 31 & 31,0 \\
\multirow{4}{*}{ Sikap } & Baik & 44 & 44,0 \\
& Kurang & 22 & 22,0 \\
\multirow{3}{*}{ Tindakan } & Cukup & 21 & 21,0 \\
& Baik & 57 & 57,0 \\
& Kurang & 31 & 31,0 \\
& Cukup & 18 & 18,0 \\
& Baik & 51 & 51,0 \\
\hline
\end{tabular}

Keterangan: $\mathrm{n}=100$ 
Tabel 8 Hubungan karakteristik internal dengan perilaku nelayan

\begin{tabular}{clccc}
\hline No & \multicolumn{1}{c}{ Karakteristik Internal } & Pengetahuan & Sikap & Tindakan \\
\hline 1 & Umur nelayan & $-0,010$ & 0,055 & $0,253^{*}$ \\
2 & Tingkat pendidikan nelayan & $0,358^{* *}$ & 0,021 & 0,061 \\
& & & & \\
3 & Jumlah tanggungan keluarga & 0,095 & $-0,053$ & $0,202^{*}$ \\
& nelayan & $0,221^{*}$ & 0,003 & 0,186 \\
4 & Pendapatan rumah tangga nelayan & $-0,013$ & $0,199^{*}$ & $0,201^{*}$ \\
5 & Pengalaman usaha nelayan & $-0,146$ & $-0,023$ & $-0,039$ \\
6 & Tingkat kekosmopolitan & & \\
\hline
\end{tabular}

Keterangan: *) nyata pada $\mathrm{p}<0,05 \quad * *)$ sangat nyata pada $\mathrm{p}<0,01 \quad$ rs: koefisien rank Spearman

hasil lelangnya (5). Tidak dibenarkan merubah, mengalihkan aliran sungai objek lelang sehingga menimbulkan kerusakan lingkungan (6). Pengemin diwajibkan untuk mengembalikan objek lelang seperti semula kepada panitia lelanng atau pemerintah desa terhitung 31 desember tahun berikutnya (7). Pengemin tidak dibenarkan untuk memindah tangankan pengelolaan objek lelang kepada pihak lain.

Hasil analisis menunjukkan bahwa sebanyak $41,0 \%$ dari responden memiliki kesadaran dalam kategori baik terhadap peraturan yang telah ditetapkan oleh lembaga lebak lebung atau pemerintah. Hal ini dapat disimpulkan bahwa responden atau pengemin menyadari dan mengetahui peraturan yang ditetapkan oleh pemerintah desa/ kelembagaan lebak lebung, dengan adanya peraturan tersebut nelayan/pengemin selalu berusaha untuk mematuhi peraturan dalam melakukan kegiatan usaha penangkapan ikan dilebak lebung. Namun sebanyak 39,0\% dari responden kurang memahami peraturan yang telah ditetapkan oleh lembaga lebak lebung atau pemerintah, sehingga tidak jarang dijumpai pelaku pelanggaran terhadap peraturan, selain itu kurangnya kesadaran responden terhadap keberlangsungan ekosistem perairan menjadi salah satu penyebab responden melakukan pelanggaran. Menurut Tampubolon dan Satria (2013) pelaksanaan peraturan yang tidak berjalan secara efisen ini disebabkan oleh beberapa faktor, yaitukurangnya sosialisasiperaturanyang dilakukan oleh pemerintah maupun pihak-pihak yang menetapkan peraturan sehingga pengetahuan masyarakat terhadap peraturan mini. Keinginan masyarakat untuk melakukan peraturan yang sudah ditetapkan juga rendah. Penegakan hukum yang lemah. Sosialisasi yang rendah dan keinginan masyarakat yang rendah untuk mematuhi peraturan.

\section{Sanksi dalam Lelang Lebak Lebung}

Sanksi dalam kegiatan lelang lebak lebung merupakan hukuman yang diberikan oleh lembaga lelang kepada pelanggar aturan atas perbuatan yang telah dilakukannya dengan tujuan agar pelaku pelanggaran tidak lagimengulangiperbuatannyadansebagaicontohjugauntuk nelayan lain agar tidak melakukan pelanggaran. Pemberian sanksi kepada pengemin/nelayan yang melanggar aturan maka pelanggar aturan akan diberikan sanksi secara bertahap sesuai dengan aturan yang berlaku. Pertama-tama diberikan peringatan secara lisan sekaligus peringatan keras terhadap pelanggar aturan penangkapan ikan. Kedua, apabila nelayan/pengemin melakukan pelanggaran maka lembaga lebak lebung atau pemerintah daerah dapat mencabut hak nelayan/pengemin atas kepemilikan objek lelang, dengan segala kerugian yang dialami menjadi resiko bagi nelayan/pengemin. Kemudian, pelanggaran ketiga langsung diselesaikan secara hukum dengan melaporkannya kepada yang berwajib. Menurut Redjeki (2012) hukuman sangat diperlukan untuk meningkatkan kedisiplinan dan mendidik manusia, supaya mau menaati semua peraturan-peraturan yang telah ditetapkan, dalam pemberian hukuman tersebut harus adil dan tegas. Karena dengan keadilan dan ketegasan, maka sasaran pemberian hukuman akan dapat tercapai, namun apabila peraturan tanpa dibarengi dengan pemberian hukuman yang tegas bagi pelanggarnya berarti bukan menjadi alat mendidik.

Berdasarkan hasil penelitian dapat dilihat bahwa sebanyak 43,0\% responden dalam kategori baik, artinya pengetahuan responden terhadap sanksi yang akan diberikan atau diterimanya apabila responden/ nelayan melakukan pelanggaran terhadap aturan. Secara keseluruhan responden menyadari dan mengetahui sanksi yang ditetapkan oleh pemerintah desa/ kelembagaan 
Tabel 9 Hubungan kelembagaan Lebak Lebung dengan perilaku nelayan di Kabupaten Muara Enim

\begin{tabular}{clccc}
\hline No & Variabel & Pengetahuan & Sikap & Tindakan \\
\hline 1 & Sejarah & 0,161 & $-0,095$ & $-0,022$ \\
2 & Peraturan & 0,106 & $0,201^{*}$ & $-0,048$ \\
3 & Sanksi & 0,005 & $-0,120$ & $0,201^{*}$ \\
\hline
\end{tabular}

Keterangan : *) nyata pada $\mathrm{p}<0,0 \quad * *)$ sangat nyata pada $\alpha<0,01 \quad$ rs: koefisien rank Spearman

lebak lebung, ketetapan peraturan ini dituangkan dalam surat keputusan desa tentang objek lelang, pembagian hasil, peraturan lelang lebak lebung Kecamatan Sungai Rotan. Nelayan/pengemin menyadari bahwa didalam pengelolaan lelang lebak lebung harus sesuai dengan aturan yang telah ditetapkan dan pelanggaran aturan akan dikenakan sanksi sesuai dengan jenis pelanggaran yang dilakukan.

\section{Karakteristik Eksternal Nelayan}

Karakteristik eksternal dalam penelitian ini meliputi kinerja kelompok nelayan dan kebijakan pemerintah. Kelompok nelayan adalah suatu kelompok yang dibentuk berdasarkan jenis mata pencaharian atau profesi yaitu sebagai nelayan. Setiap kelompok nelayan memiliki identitas atau karakter tersendiri sebagai cerminan kondisi internal dari suatu kelompok. Kondisi internal yang membentuk atau menjadi suatu identitas suatukelompoknelayan adalah kondisi lingkungan tempat kelompok nelayan berada, karakteristik keanggotaan, sarana prasarana kelompok dan aturan kelompok yang berlaku.

Kinerja kelompok nelayan tergolong rendah, hal ini dapat dilihat bahwa sebanyak $43,0 \%$ dari responden memiliki tingkat kinerja kelompok dalam kategori kurang. Dapat disimpulkan bahwa secara keseluruhan kelompok nelayan atau pengemin lelang lebak lebung belum maksimal dalam melakukan kegiatan usahanya. Dengan kata lain tujuan kelompok nelayan belum tercapai sepenuhnya hal ini juga dipaparkan oleh salah seorang responden bahwa mereka sering mengalami kerugian dalam usahanya seperti biaya operasional kelompok tidak sesuai dengan pendapatan yang diperoleh hal ini disebabkan oleh rendahnya hasil tangkapan ikan yang diperoleh responden. Selain itu terbatasnya kemampuan, pengalaman, perencanaan kerja, kemampuan dalam mengemukakan pendapat dan pengambilan keputusan dalam usaha menjadi penyebab masih rendahnya kinerja kelompok nelayan dalam mengembangkan usahanya. Sejalan dengan temuan penelitian Wahyuni (2003) bahwa kinerja mayoritas kelompok tani masih rendah dan memerlukan bimbingan. Hal ini disebabkan mayoritas kelompok tani masih pada tingkatan pemula. Berbagai usaha untuk meningkatkan kinerja kelompok telah dilakukan dengan hasil yang bervariasi.

Kebijakan Pemerintah Daerah Kabupaten Muara Enim tentang pengelolaan perairan umum dengan melakukan lelang lebak lebung, pada dasarnya mempunyai tujuan untuk membina, mengawasi dan mengembangkan produktifitas sumber daya alam di dalamnya agar terpelihara dengan baik untuk kesejahteraan masyarakat. Pelaksanaan Peraturan Daerah dalam proses pengelolaan lebak lebung di Kabupaten Muara Enim memberikan keuntungan baik secara financial maupun non financial kepada masyarakat khususnya nelayan/pengemin atas potensi perikanan perairan umum. Menurut Ostrom (2000)pengembangan kebijakan publik yang meningkatkan bermanfaat secara sosial, perilaku kooperatif sebagian didasarkan pada norma-norma social, namun pendapat ini bertentangan dengan pendapat Syahrizal (2011) yang menyatakan bahwa program pembangunan perikanan dengan modernisasi atau intensifikasi modal telah menyebabkan meningkatnya produksi perikanan akan tetapi hal tersebut tidak secara otomatis meningkatkan taraf hidup nelayan pada umumnya. Kebijakan pembangunan perikanan menimbulkan konflik dalam masyarakat nelayan, nelayan yang tidak memiliki modal hasil tangkapannya semakin berkurang. Pemerintah Kabupaten Muara Enim membentuk tim-tim yang mempunyai tugas masingmasing sebagai pengawas dan pengelola atas berjalannya proses peretribusian dan pelelangan objek lebak lebung, sungai, danau dan rawa-rawa.

Pemerintah daerah memiliki tugas penting dalam pengelolaan sektor perikanan. Dalam pengelolaan perikanan ini perlu memperhatikan kebijakan yang telah dibuat maaupun yang akan dibuat oleh pemerintah di Kabupaten Muara Enim. Hasil penelitian menunjukkan bahwa kebijakan pemerintah dalam pengelolaan perairan umum lebak lebung melalui lelang tergolong tinggi, dapat dilihat sebanyak 40,0\% responden dalam kategori baik. 
Tabel 10 Hubungan karakteristik eksternal dengan perilaku nelayan di Kabupaten Muara Enim

\begin{tabular}{llccc}
\hline No & Karakteristik Eksternal & Pengetahuan & Sikap & Tindakan \\
\hline 1 & Kinerja kelompok nelayan & 0,117 & $0,202^{*}$ & $-0,008$ \\
2 & Kebijakan pemerintah & 0,038 & $0,242^{*}$ & $-0,063$ \\
\hline
\end{tabular}

Keterangan : *) nyata pada $\mathrm{p}<0,0 \quad * *)$ sangat nyata pada $\alpha<0,01$ rs: koefisien rank Spearman

Hal ini dapat disimpulkan bahwa secara keseluruhan kebijakan yang dikeluarkan oleh pemerintah daerah dalam upaya pengelolaan perairan umum dengan cara lelang merupakan langkah yang tepat untuk masyarakat khususnya masyarakat nelayan diwilayah ini, mengingat mata pencaharian masyarakat daerah tersebut sangat bergantung kepada perairan umum, kebijakan harus disesuaikan dengan kondisi perkembangan rumah tangga perikanan dilihat dari tingkat kesejahteraan rumah tangga nelayan yang ada didaerah Kabupaten Muara Enim khususnya Kecamatan Sungai Rotan. Selanjutnya dalam pelaksanaan kebijakan tersebut lembaga lebak lebung atau pemerintah selalu mengsosialisasikan atau menyampaian informasi yang berhubungan dengan kebijakan atau peraturan pengelolaan lelang lebak lebung kepada masyarakat nelayan, agar nelayan mengetahui dan memahami peraturan dan kebijakan pemerintah. Namum dalam pelaksanaannya kebijakan pengelolaan lelang lebak lebung ini telah diatur sedemikian rupa, tetapi tidak sedikit dari responden tidak mengetahui bahkan tidak ingin mengetahui isi dari kebijakan yang telah ditetapkan oleh lembaga lebak lebung atau pemerintah, kurangnya kesadaran nelayan menjadi salah satu penyebab musnahnya habitat ikan yang ada diperairan lebak lebung.

\section{Perilaku Nelayan}

Perilaku nelayan yang dianalisis dari aspekaspek: pengetahuan, sikap dan tindakan nelayan dalam melakukan pengolahan dan menjaga perairan lebak lebung. Pengetahuan adalah hasil yang diketahuai atau diperoleh seseorang atau nelayan setelah melakukan pengindraan terhadap suatu objek tertentu. Pengindraan terjadi melalui panca indra manusia, yaitu indra penglihatan, pendengaran, penciuman, rasa dan raba. Sebagian besar pengetahuan manusia di peroleh melalui mata dan telinga (Notoatmodjo, 2003). Perilaku masyarakat nelayan sangat bergantung pada pengetahuan dan sikap yang selalu berusaha untuk meningkatkan kemampuan/ keterampilan yang dilakukan dalam perbuatan nyata. Menurut Jhon et al.,
(2010) rusaknya keanekaragaman hayati sebagain besar disebabkan oleh perilaku manusia, dengan demikian perilaku manusia harus diperbaiki dengan memperluas pengetahuan dan keterampilan. Pengetahuan dan sikap akan berubah menjadi suatu tindakan dalam bentuk perbuatan nyata untuk memperbaiki hidup.

Pengetahuan responden tentang periaran lebak lebung mencakup manfaat secara ekonomi dan ekologis serta pelestarian perairan lebak lebung. Pengetahuan responden dikelompokkan menjadi tiga kelompok yaitu, kurang, cukup dan baik. Kriteria pengelompokkan berdasarkan pada jawaban atas pernyataan yang diajukan kepada responden. Berdasarkan analisis dapat diketahui bahwa pengetahuan responden tentang manfaat dan pelestarian lebak lebung, sebanyak $44,0 \%$ responden dalam kategori baik. Responden telah memahami manfaat dari perairan lebak lebung, namun pengetahuan responden masih sangat terbatas, responden tidak pernah berpikir bahwa ekositem perairan lebak lebung semakin habis, hal ini diakibatkan oleh keserakahan para pengemin atau pemenang lelang dalam menangkap ikan tanpa memperdulikan keberlanjutan ekosistem ikan tersebut. Semakin baik tingkat pengetahuan responden tentang pengelolaan dan pelestarian lebak lebung maka semakin baik pula tindakan responden dalam melakukan pengelolan lebak lebung yang menjadi tempat mereka menggantungkan kehidupannya, dengan harapan bahwa responden melakukan kegiatan usahanya diperairan lebak lebung juga ikut berpartisipasi dalam menjaga kelestarian lingkungan perairan dan juga ekosistem perairan. Pengetahuan tentang pengelolaan perairan lebak lebung diperoleh responden dari pengalaman selama berinteraksi dengan perairan lebak lebung.

Sikap merupakan suatu bentuk evaluasi atau reaksi perasaan seseorang terhadap suatu objek baik perasaan mendukung atau perasaan tidak mendukung pada objek tersebut. Hasil penelitian menunjukkan bahwa sikap yang dimiliki responden dalam pengelolaan perairan lebak lebung tergolong dalam kategori baik, hal ini dapat dilihat sebanyak 
57,0\% responden dalam kategori baik. Hal ini dapat diartikan bahwa secara keseluruhan bahwa responden memiliki sikap positif terhadap pengelolaan perairan umum lelang lebak lebung, walaupun belum seluruh sikap yang terbentuk terwujud dalam tindakan nyata oleh responden. Sikap positif responden terlihat dari ketaatan responden terhadap status kawasan objek lebak lebung serta batas kawasan lebak lebung yang telah ditetapkan lembaga lebak lebung, sebagian besar dari responden melakukan pemanfaatan hasil lebak lebung sesuai peraturan yang ditetapkan lembaga lebak lebung. Menurut Hartati et al., (2005) dalam penelitiannya menyebutkan bahwa sikap positif yang diberikan oleh sebagian besar responden diduga berkaitan dengan pengetahuannya tentang pentingnya upaya pelestarian, dimana dalam hal ini pelestarian perairan lebak lebung. Selanjutnya Notoatmodjo (2003) mengemukakan bahwa sikap adalah kecenderungan untuk bertindak (praktek), sikap belum tentu terwujud dalam tindakan, sebab untuk terwujudnya tindakan perlu faktor lain, yaitu antara lain adanya fasilitas atau sarana dan prasarana.

Tindakan yang dimaksud dalam penelitian ini adalah perbuatan nyata yang dilakukan oleh responden dalam upaya pemanfaatan dan pelestarian perairan lebak lebung. Hasil penelitian menunjukkan bahwa tindakan atau perbuatan nyata yang dilakukan oleh responden tergolong baik, dapat dilihat sebanyak $51,0 \%$ responden melakukan tindakan dalam pemanfaatan perairan lebak lebung dan pelestarian perairan lebak lebung dan ekosistemnya dalam kategori baik. Hal ini dapat diartikan bahwa responden melakukan perbuatan nyata dalam bentuk tindakan dengan menjaga keamanan wilayah perairan lebak lebung, responden melakukan pencegahan dan tidak melakukan penangkapan dengan menggunakan alat tangkap terlarang, responden melakukan pemanfaatan hasil perairan sesuai peraturan lembaga lebak lebung atau pemerintah. Responden menyadari arti pentingnya perairan bagi kehidupan mereka, diikuti dengan bukti perbuatan nyata sebagian besar nelayan tidak merusak lingkungan perairan dan ekosistem perairan dengan menggunakan alat tangkap terlarang seperti bahan peledak dan bahan kimia lainnya. Menurut Notoatmodjo (2003) rangsangan yakni objek yang telah diketahui dan disadari sepenuhnya tersebut akan menimbulkan suatu tindakan terhadap stimulus atau objek tersebut sehingga terbentuk suatu perilaku hidup individu.

\section{Hubungan Karakteristik Internal dengan Perilaku Nelayan}

Umur nelayan, tingkat pendidikan nelayan, jumlah tanggungan keluarga nelayan, pendapatan rumah tangga nelayan, pengalaman usaha nelayan, dan tingkat kekosmopolitan berhubungan dengan perilaku nelayan yang meliputi pengetahuan, sikap, dan tindakan (Tabel 8).

Umur nelayan tidak berkorelasi terhadap pengetahuan dan sikap, hal ini sejalan dengan penelitian yang dilakukan oleh Hartati et al., (2005) yang menunjukkan bahwa umur responden tidak berkorelasi dengan pengetahuannya tentang mangrove. Selanjutnya tidak terdapat korelasi nyata antara umur dengan sikap responden terhadap rehabilitasi mangrove. Hasil ini memberikan indikasi tidak terdapat kecenderungan bahwa semakin tua umur responden semakin baik pengetahuan dan sikapnya terhadap rehabilitasi mangrove. Umur nelayan berkorelasi nyata dengan tindakan nelayan dalam pengelolaan perairan lebak lebung, dengan semakin tua umur nelayan maka akan semakin positif tindakan yang dilakukan nelayan dalam melakukan usaha penangkapan ikan serta semakin positif tindakan nelayan dalam pengelolaan perairan lebak lebung. Tingkat pendidikan berhubungan nyata dengan pengetahuan dalam pengelolaan perairan lebak lebung, dengan semakin tinggi tingkat pendidikan nelayan maka akan semakin tinggi pula tingkat pengetahuan yang dimiliki oleh nelayan dalam upaya pengelolaan perairan lebak lebung. Hal ini sejalan denganpendapatyang dikemukan oleh Slamet(1992), bahwa pendidikan seseorang mempengaruhi perilaku individu baik dari segi pengetahuan, sikap maupun keterampilan.

Menurut Rifai (2002) banyaknya jumlah anggota rumah tangga perikanan dapat menjadi beban bagi kepala rumah tangga karena semakin banyak jumlah anggota keluarga maka diperlukan biaya yang banyak pula untuk kebutuhan hidup. Namun sebaliknya anggota keluarga yang banyak dapat dijadikan sebagai modal tenaga kerja dalam membantu pekerjaan nelayan untuk menunjang ekonomi keluarga dengan kontribusi pendapatan yang dihasilkan oleh istri dan anak-anak mereka. Jumlah tanggungan keluarga nelayan berhubungan nyata dengan tindakan nelayan, hal ini dapat diartikan bahwa semakin besar jumlah tanggungan nelayan maka akan semakin positif tindakan dan usaha nelayan untuk memenuhi kebutuhan keluarganya. Tingkat ketergantungan nelayan terhadap perairan dalam memenuhi perekonomian keluarganya menjadi salah satu alasan nelayan untuk bertindak 
positif dan sebaik mungkin dalam melakukan kegiatan usaha penangkapan ikan lebak lebung agar mereka tidak kehilangan sumber mata pencahariannya.

Pendapatan rumah tangga nelayan juga berhubungan nyata terhadap pengetahuan, hal ini dapat diartikan bahwa tingkat pengetahuan nelayan sangat berpengaruh terhadap nelayan didalam menentukan strategi untuk melakukan pengelolaan perairan lebak lebung guna mendapatkan hasil yang maksimal dan meningkatkan pendapatan nelayan. Sesuai dengan pendapat Mar'at (1981), pengetahuan yang dimiliki oleh individu akan menentukan sikap bagi manusia yang mengarahkan dirinya kepada tindakan. Hal ini bertentangan dengan penyataan Hartati et al., (2005) pendapatan tidak berhubungan dengan tingkat pengetahuan responden, tidak terdapat kecenderungan bahwa semakin tinggi tingkat pendapatan responden akan semakin baik pula tingkat pengetahuan responden.

Pengalaman usaha nelayan tidak berhubungan dengan pengetahuan. Hal ini sejalan dengan penelitian yang dilakukan oleh Hartati et al., (2005) bahwa lama berusaha bisa dianggap sebagai pengalaman berusaha bagi responden, namun lama berusaha tidak berhubungan dengan pengetahuan. lamanya pengalaman responden tidak menunjukkan kemampuan/kecepatan responden untuk menerima informasi tentang manfaat dan pelestarian. Hal ini terkait dengan minimnya kegiatan penyuluhan yang diberikan kepada responden dalam upaya peningkatan pengetahuannya. Pengalaman usaha nelayan berhubungan nyata dengan sikap dan tindakan nelayan dalam pengelolaan perairan lebak lebung, hal ini dapat diartikan bahwa pengalaman yang diperoleh nelayan dari kegiatan usaha penangkapan ikan diperairan lebak lebung sangat berperan penting dalam pembentukan sikap serta tindakan yang harus dilakukan oleh nelayan dalam pengelolaan perairan lebak lebung, tingginya pengalaman usaha nelayan maka akan semakin tinggi sikap positif nelayan terhadap pelestarian perairan lebak lebung dan semakin positif pula tindakan yang dilakukan nelayan didalam melakukan usaha penangkapan ikan serta pelestarian perairan lebak lebung. Menurut Padmowihardjo (2002), pengalaman, baik yang menyenangkan maupun yang mengecewakan akan mempengaruhi proses belajar seseorang.

\section{Hubungan Kelembagaan Lebak Lebung dengan Perilaku Nelayan}

Sejarah, peraturan, dan sanksi berhubungan dengan perilaku nelayan yang meliputi pengetahuan, sikap, dan tindakan (Tabel 9). Peraturan berhubungan nyata dengan sikap nelayan dalam pengelolaan perairan lebak lebung.

Hal ini dapat diartikan bahwa semakin tegas peraturan yang ditetapkan oleh lembaga lebak lebung atau pemerintah daerah maka akan semakin positif sikap nelayan dalam melakukan usaha penangkapan ikan serta tidak melakukan perbuatan yang bersifat negatif dalam melakukanan penangkapan ikan atau kegiatan usahanya, selain itu dengan adanya peraturan yang ditetapkan oleh lembaga lebak lebung atau pemerintah nelayan juga mempunyai acuan atau pedoman dalam melakukan kegiatan usahanya dan nelayan bertindak sesuai aturan yang sudah ditetapakn lembaga lebak lebung. Sejalan dengan pendapat Ostrom (1990) menilai bahwa arena pilihan kolektif dan operasional sangat dipengaruhi oleh arena pilihan konstitusional. Hal ini dapat diartikan bahwa peraturan konstitusional terkait pengelolaan lelang lebak lebung harus diimplementasikan ditingkat daerah untuk pengelolaan perairan umum lebak lebung.

Sanksi dalam pengelolaan lelang lebak lebung merupakan hukuman yang akan diterima oleh pelaku pelanggaran peraturan lelang lebak lebung, hasil analisis statistik memberikan hasil yang signifikan antara sanksi dan tindakan nelayan dalam pengelolaan perairan lebak lebung. Hal ini dapat diartikan bahwa semakin tegas sanksi yang ditetapkan dan diterapkan maka semakin positif tindakan yang nelayan hal ini disebabkan oleh rasa takut yang akan muncul dalam diri nelayan untuk melakukan pelanggaran. Sejalan dengan penelitian Stanis (2007) yang menjelaskan bahwa dengan adanya sanksi tersebut cukup efektif dan membuat jera tindakan nelayan yang biasanya melakukan merusak sumberdaya alam pesisir dan laut.

Perilaku dan peradaban masyarakat seperti di atas ternyata memberi makna positif bagi upaya konservasi dan rehabilitasi sumberdaya pesisir dan laut. Pengelolaan lelang lebak lebung, lembaga lebak lebung menetapkan peraturan-peraturan yang harus ditaati oleh nelayan, sejalan dengan peraturan yang ditetapkan lembaga lebak lebung juga telah menetapkan sanksi untuk setiap pelaku pelanggaran peraturan.

\section{Hubungan Karakteristik Eksternal dengan Perilaku Nelayan}

Kinerja dari rerata kelompok nelayan, kebijkan pemerintah berhubungan dengan perilaku nelayan 
yang meliputi pengetahuan, sikap, dan tindakan (Tabel 10). Hasil penelitian menunjukkan kinerja kelompok nelayan berkorelasi positif terhadap sikap nelayan dalam pengolahan perairan lebak lebung. Hal ini dapat diartikan bahwa semakin baik kinerja nelayan dalam melakkukan kegiatan pengolahan perairan lebak lebung maka akan semakin positif sikap nelayan terhadap pengelolaan perairan lebak lebung, hal ini disebabkan karena sifat ketergantungan nelayan terhadap perairan yang menuntut mereka untuk melakukan pengolahan perairan lebak lebung dengan cara sebaik baiknya agar ekosistem perairan tidak musnah dan kegiatan kearifan lokal lelang lebak lebung tetap terjaga. Peningkatan kinerja kelompok nelayan diperlukan pendampingan kelompok, hal ini sejalan dengan pendapat Wahyuni (2003) suatu pendekatan atau metode pemberdayaan yang mampu mendorong peningkatan kinerja kelompok tani.

Kebijakan pemerintah berkorelasi secara nyata terhadap sikap nelayan dalam pengelolaan perairan lebak lebung, hal ini dapat diartikan bahwa kebijakan pemerintah berperan penting dalam pembentukan perilaku nelayan dalam pengelolaan perairan lebak lebung, dengan semakin tegas peraturan yang ditetapkan pemerintah dan semakin tinggi sosialisasi dan penyampaian informasi dari pemerintah maka akan semakin positif sikap nelayan. Merujuk kepada temuan penelitian Prihandoko (2012) bahwa peningkatan sikap positif nelayan dapat dilakukan dalam bentuk pemberian informasi. Dukungan pemerintah dalam pengelolaan perairan umum mempunyai peranan penting bagi masyarakat dan keberlanjutan perikanan. Hal ini sejalan dengan penelitian yang dilakukan oleh Herman et al., (2006) yang menjelaskan bahwa dukungan pemerintah sangat dibutuhkan dalam mempertahankan keberlanjutan pertanian. Sosialisasi kebijakan pemerintah disampaikan langsung oleh lembaga lebak lebung atau pemerintah desa baik secara langsung ataupun tidak langsung dengan tujuan informasi mampu diterima oleh nelayan dan dilaksanakan sesuai kebijakan yang telah ditetapkan oleh pemerintah.

\section{Kesimpulan}

Berdasarkan hasil penelitian maka simpulan penelitian ini (1) lebak lebung merupakan perairan umum yang terdiri dari sungai dan tanah yang bentuk rawa-rawa (lebak) dan tanah rendah yang tergenang air (lebung). Pengemin/pemenang lelang memiliki hak penuh untuk menangkap ikan dan hasil perairan lebak lebung merupakan milik pengemin/pemenang lelang yang sudah memenangkan objek lebak lebung melalui kegiatan lelang. Lelang lebak lebung diselenggarakan dengan tujuan untuk memperoleh pendapatan daerah (PAD), pelestarian perairan umum lebak lebung, dan menghindari konflik antar nelayan (2) perilaku nelayan yang terdiri dari pengetahuan, sikap dan tindakan nelayan dalam pengelolaan perairan lebak lebung termasuk dalam kategori tinggi dan (3) karakteristik internal, kelembagaan lebak lebung dan karakteristik eksternal yang berhubungan dengan perilaku nelayan adalah umur, tingkat pendidikan, jumlah tanggungan, pengalaman usaha nelayan, pendapatan nelayan, aturan, sanksi, kinerja kelompok nelayan, kebijakan pemerintah.

\section{Daftar Pustaka}

Arifin Z. 1978. Beberapa Aspek tentang Penangkapan Ikan di Perairan Umum Lubuk Lampam, Sumatera Selatan, Laporan Penelitian Lembaga Penelitian Perikanan Darat Cabang. Palembang (ID).

Daris L, Kartika EZ, Aminuddin S. 2012. Dinamika Konflik dan Peran Kelembagaan Lokal dalam Pengelolaan Sumberdaya Perikanan Tangkap di Kabupaten Maros Provinsi Sulawesi Selatan. Jurnal Agrisistem 8(1): 32-42.

Evans TP, Daniel HC. 2014. Contextualizing the Influence of Social Norms, Collective Action Onsocial-Ecological Systems. Journal of Natural Resources Policy Research 6(4): 259-264.

Garnadi D. 2004. Pengetahuan, Sikap dan Tindakan Masyarakat Sekitar Hutan Terhadap Hutan. [tesis]. Bogor (ID): Pascasarjana IPB.

Hartati T, Amanah S, Sobari MP. 2005. Perilaku Petambak dalam Konservasi Hutan Mangrove di Desa Jayamukti Kabupaten Subang Provinsi Jawa Barat. Buletin Ekonomi Perikanan 6(1) : 13-36.

Herman, Hutagaol MP, Sutjahjo SH, Rauf A, Priyarsono DS. 2006. Analisis Faktor-faktor yang Mempengaruhi Adopsi Teknologi Pengendalian Hama Penggerek Buah kakao: studi kasus disulawesi selatan. Jurnal Pelita Perkebunan 22(3): 222-236.

Mar'at. 1981. Sikap Manusia, Perubahan Serta 
Pengukurannya. Bandung (ID): Ghalia Indonesia.

Marliati, Sumardjo, Asngari PS, Tjitropranoto P, Saefuddin A. 2008. Faktor-Faktor Penentu Peningkatan Kinerja Penyuluh Pertanian dalam Memberdayakan Petani. Jurnal Penyuluhan 4(2): 92-99.

Nasution Z. 2008. Perkembangan Ekonomi Masyarakat Nelayan Perairan Umum "Lebak Lebung”. Jurnal Transdisiplin Sosiologi, Komunikasi dan Ekologi Manusia 2(2): 239255.

Nasution Z. 2012. Kelembagaan Pengelolaan Sumberdaya Perikanan"Lelang Lebak Lebung" dan Kemiskinan Nelayan (Study Kasus di Kabupaten Ogan Komering Ilir, Sumatera Selatan). [disertasi]. Bogor (ID): Program Pascasarjana, Institut Pertanian Bogor.

Notoatmodjo S. 2003. Prinsip-Prinsip Dasar Ilmu Kesehatan Masyarakat. Jakarta (ID): PT. Rineka Cipta.

Ostrom E. (1990). Governing the Commons: The Evolution of Institutions for Collection Action. Cambridge: Cambridge University Press.

Ostrom E. 2000.Collective Action and the Evolution of Social Norms. Journal of Economic Perspectives 14(3): 137-158.

Pakpahan HT, RWE Lumintang, Susanto D. 2006. Hubungan Motivasi Kerja dengan Perilaku Nelayan pada Usaha Perikanan Tangkap. Jurnal Penyuluhan 2(1). 26-34

Padmowihardjo. 2002. Pembangunan Pertanian: Sebelum dan Pasca Krisis Pergeseran Paradigma dan Pengembangan SDM dan Pendukungnya. Medan.

Pemda Tk I Prop. 1974. Peraturan Daerah Tingkat I Propinsi Sumatera Selatan (Sumsel) No. 8/ Perdass/1973/1974 tgl. 14 Juli 1974, Lembaran Daerah Prop. Sumsel tgl. 26 Nopember 1974 Seri A No. 14. Salinan dari Dinas Perikanan Perikanan Tk I Prop. Sumsel.

Pemda Tk I Prop. 1978. Peraturan Daerah Tingkat I
Propinsi Sumatera Selatan No. 6 Tahun 1978 tgl. 6 Mei 1978. tentang Mengubah untuk Pertama Kalinya Perda Prop. Dati I Sumsel Tentang Lelang Lebak Lebung, Lembaran Daerah Prop. Sumsel tgl. 30 September 1978 Seri D.

Prihandoko, Jahi A, Gani DS, Purnaba IGP, Adrianto L, Tjitradjaja I. 2012. Faktor-Faktor yang Mempengaruhi Perilaku Nelayan Artisanal dalam Pemanfaatan Sumberdaya Perikanan di Pantai Utara Provinsi Jawa Barat. Jurnal Penyuluhan 8(2): 158-175.

Redjeki, Sri DP. 2012. Memelihara dan Meningkatkan Kedisiplinan yang Baik. Jurnal Stie Semarang 4(1): 1-12.

Slamet. 1992. "Perspektif Ilmu Penyuluhan Pembangunan dalam Menyongsong Era Tinggal Landas". Dalam Penyuluhan Pembangunan di Indonesia: Menyongsong Abad XX1. Diedit oleh Aida Vitayala Sjafri Hubeis, Prabowo Tjitropranoto, dan Wahyudi Ruwiyanto. Jakarta: PT Pustaka Pembangunan Swadaya Nusantara.

Stefanus S, Supriharyono, Bambang AN. 2007. Pengelolaan Sumberdaya Pesisir dan Laut melalui Pemberdayaan Kearifan Lokal di Kabupaten Lembata Propinsi Nusa Tenggara Timur. Jurnal Pasir Laut 2(2): 67-82.

Sugiyono. 2011. Metode Penelitian Kuantitatif Kualitatif dan R\&D. Bandung (ID): Alfabeta: 80-91.

Syahrizal, Meiyenti S, Ekaputra R. 2011. Aspek Tindakan dan Perilaku dalam Kemiskinan: Studi pada Masyarakat Nelayan Kabupaten Pesisir Selatan Sumatera Barat. Jurnal Humanus 10(1): 25-35.

Tampubolon F, Satria A. 2013. Hubungan antara Nelayan Jepara dan Karimunjawa dalam Memanfaatkan Sumberdaya Perikanan di Taman Nasional Karimunjawa. Jurnal Sosiologi Pedesaan 233-240.

Wahyuni S. 2003. Kinerja Kelompok Tani dalam Sistem Usaha Tani Padi dan Metode Pemberdayaannya. Jurnal Litbang Pertanian 22(1): 1-8. 